\title{
Germination, wettability, and imbibition of dormant seeds of Desmanthus virgatus after low-pressure plasma treatment
}

\author{
Germinação, molhabilidade e embebição de sementes de \\ (Desmanthus virgatus (L.) Willd.) após tratamento a plasma baixa pressão
}

\author{
Dinnara Layza Souza da Silva* (1), Maria Verônica Meira de Andrade² (i), Danilo Cavalcanti Braz ${ }^{3}$ (1), \\ Rômulo Ribeiro Magalhães de Sousa ${ }^{4}$ (1), Mérik Rocha Silva 5 (1), Renan Matos Monção (1)
}

\begin{abstract}
The use of an alternative technique to increase the germination of an legume species used in animal feed was investigated based on the effects of low-pressure plasma on the wettability, imbibition, and germination of seeds of Desmanthus virgatus. A conventional nitriding reactor with an argon atmosphere (Ar) and controlled temperature at $30^{\circ} \mathrm{C}$ was used to apply three different exposure times: 1,3 , and 5 minutes, with a set of intact seeds considered as the control. The experimental design was completely randomized, and the means were compared by the Tukey test at $5 \%$ probability to analyze the different experimental conditions tested. The statistical analyses were performed with the software Origin 8.0. The apparent contact angle indicated an increase in the wettable surface with the treatment time, verifying the hydrophilic character of the plasma on the seed. Seeds treated for 3 and 5 minutes showed higher germination than the 1-minute treatment and untreated seeds. In the imbibition test, the leached solution showed lower conductivity in the treated samples than in the untreated sample, indicating less nutrient loss to the solution. The $\mathrm{pH}$ remained within the neutral range among the treated samples. The superficial changes in the seeds caused significant gains in the germination parameters, promoting improvement in the indices and rate of germination and contributing to the uniformity of the seed lot with the use of lowpressure plasma as a tool for breaking dormancy.
\end{abstract}

KEYWORDS: Physical dormancy; Jureminha; Leguminous.

RESUMO: Foi investigado o uso de técnica alternativa com fins ao aumento da germinação de uma espécie de leguminosa empregada na alimentação animal, a partir dos efeitos do plasma em baixa pressão na molhabilidade, embebição e germinação de Desmanthus virgatus. Utilizou-se reator de nitretação convencional com atmosfera de argônio (Ar) e temperatura controlada em $30^{\circ} \mathrm{C}$ sob tratamento de três diferentes tempos de exposição 1,3 e 5 minutos, considerou-se conjunto de sementes intactas como controle. O delineamento utilizado foi inteiramente casualizado, os resultados submetidos ao teste de Tukey à $5 \%$ para análise das médias entre as condições experimentais testadas, as análises estatísticas foram realizadas no programa Origin 8.0. O ângulo de contato aparente indicou aumento da superfície molhável com o tempo de tratamento comprovando caráter hidrofílico do plasma na semente. Sementes tratadas por 3 e 5 minutos apresentaram germinaçáo superior ao tratamento por 1 minuto e em relação as sementes sem tratamento. A solução lixiviada, no teste de embebição apresentou condutividade das amostras tratadas menor que a amostra sem tratamento, indicando menor perda de nutrientes para a solução. $\mathrm{O}$ pH permaneceu-se dentro da faixa de neutralidade para as amostras tratadas. As modificaçóes superficiais nas sementes ocasionaram ganhos significativos nos parâmetros germinativos, promovendo melhoria nos índices e percentagem de germinaçáo, e contribuindo na uniformidade do lote de sementes com o uso do plasma a baixa pressáo como ferramenta para quebra de dormência.

PALAVRAS-CHAVE: Dormência física; Jureminha; Leguminosas. 


\section{INTRODUCTION}

Plasma technology has been widely used in agriculture, especially in microbial inactivation and seed dormancy breaking (ALVES JR. et al., 2019; ALVES JR. et al., 2020; SILVA et al., 2018). The use of low-pressure plasma has been highlighted due to its several applications and for being a process without environmental impacts.

The obtainment of good results in surface modification occurs through physicochemical properties, providing a reliable and reproducible quality control that is less likely to be achieved by the most commonly used techniques.

Some points should be considered as challenges to be overcome regarding low-pressure plasma, such as the need to use a vacuum system, which is essential to control the atmosphere generated in the process and selecting the chemical species formed, thus increasing the cost of the process. Furthermore, temperature control is necessary when the objective is to treat biological surfaces, such as seeds.

Studies on the use of plasma for seed treatment aim to overcome dormancy and potentialize the germination process. This technique has been widely used with species of commercial interest, such as soybean, and forest species used for reforestation, such as Sabiá (Mimosa caesalpiniaefolia) (SILVA et al., 2018).

Desmanthus virgatus was chosen due to its important characteristics for agriculture and cattle raising, being a perennial legume that grows in various adaptable territories of the American continent.

The species is used as a protein source to feed herds during food shortages and has the potential to be used in the reforestation of degraded areas (ANDRADE et al., 2020). However, its propagation is hindered by seed coat dormancy, which causes structural impermeability and is responsible for restricting water entry and gas exchange processes in the seed.

This can hinder the growth of the embryo and result in slow and uneven germination, representing an obstacle to planned planting. In this context, several dormancy breaking techniques are used to structurally modify the seed coat of several seed types, such as mechanical scarification, chemical treatment, immersion in hot water, and blade incision.

However, techniques that generate environmental waste are no longer allowed in the current environmental and scientific conjuncture. In this perspective, considering the potential uses of the species, alternative and sustainable technologies that cause the least possible damage to the anatomical structure of seeds can be proposed to overcome seed dormancy, such as low-pressure plasma at controlled temperatures (SITTIDET et al., 2019; ZHANG et al., 2018).

Therefore, this study aimed to propose a protocol for the use of low-pressure plasma as a sustainable technology to improve the seed germination parameters of $D$. virgatus.

\section{MATERIAL AND METHODS}

\section{Collection of seeds of Desmanthus virgatus}

The seeds of D. virgatus were collected in March 2019, in a cultivation area located in Caxias - MA, at an elevation of 79 m (452'29"S, 43 20'49”W).

The pods were harvested in the maturation phase, put in plastic pots, and stored in a cold room at $11{ }^{\circ} \mathrm{C}$ and $10.96 \%$ of relative humidity.

\section{Experimental apparatus}

Seed modification by plasma was made using a conventional plasma nitriding reactor with a direct-current power source and maximum voltage and current of $1,500 \mathrm{~V}$ and $2 \mathrm{~A}$, respectively. The vacuum chamber is cylindrical, $30 \mathrm{~cm}$ wide and $40 \mathrm{~cm}$ long, and made of AISI 304 stainless steel.

The seeds were placed in the holes of a disk made of AISI 304 stainless steel with a diameter of $75 \mathrm{~mm}$ and a thickness of $6 \mathrm{~mm}$. Five seeds were placed in each of the 19 holes measuring $9 \mathrm{~mm}$ in diameter (Figure 1). An argon atmosphere was used at a flow rate of $10 \mathrm{sccm}$ and a temperature of $30^{\circ} \mathrm{C}$.

Treatments consisted of the following experimental conditions: Control (seeds without plasma treatment), seeds treated with low-pressure plasma and argon atmosphere at $10 \mathrm{sccm}$ for 1 minute, 3 minutes, and 5 minutes at the controlled temperature of $30^{\circ} \mathrm{C}$.

\section{Measurement of the apparent contact angle (wettability)}

The apparent contact angle was determined using seed samples treated with the different experimental conditions, with five seeds per condition.

Seed surface wettability was measured based on the sessile drop method, according to which a $16 \mu \mathrm{L}$ drop of ultrapure water was gently deposited on the seed surface, forming an angle between the drop and the surface determined by

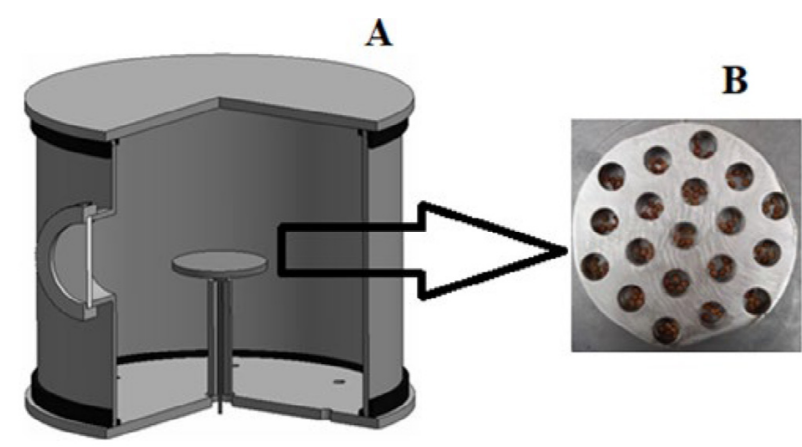

Figure 1. Experimental apparatus used for seed treatment. Design of a stainless-steel nitriding reactor $(A)$. Door containing five seeds of Desmanthus virgatus per hole (B). 
image analysis using the software CAM 2008/KSV Instruments. The apparent contact angle was determined by the arithmetic mean of 20 measurements per seed.

\section{Imbibition test, mass, $\mathrm{pH}$, and conductivity measurements}

Four replications of 25 seeds per treatment were placed in $250 \mathrm{~mL}$ plastic cups containing $200 \mathrm{~mL}$ of distilled water.

The cups were put in a germination chamber with daily 12-h light and 12-h darkness photoperiod at a constant temperature of $25^{\circ} \mathrm{C}$, according to the methodology described by Queiroz (2012).

In the imbibition test, which was used to infer the relative water absorption, seed mass was determined using an analytical balance at intervals of 3, 7, and 12 hours on the first day, followed by subsequent 12 -h intervals until the third day, and ending with measurements every 24 hours until the end of the experiment, on the twenty-third day.

Before each measurement, the seeds were placed on sterilized paper sheets to remove the excess water. The relative percentage of water absorption (imbibition) was defined according to the following equation (1).

$E(\%)=\frac{\left[\left(m_{t}-m_{o}\right)\right]}{m_{o}} \times 100 \%$

where $m_{o}$ is the total initial seed mass, and $m_{t}$ is the total seed mass for each measurement interval.

After removing the seeds to measure the mass, the imbibition liquid containing substances leached from the seeds was used to measure the electrical conductivity (CE) and the $\mathrm{pH}$ at the same intervals mentioned before. The $\mathrm{CE}$ measurements were performed with an Oakton PC 450 conductivity meter, and the measuring unit was given in $\mu \mathrm{Scm}^{-1}$. The $\mathrm{pH}$ measurements occurred immediately after the conductivity analysis using a $\mathrm{pH}$ meter.

\section{Germination test}

The germination test was conducted with 100 seeds divided into four replications of 25 seeds, according to the methodology described by Queiroz (2012). Gerbox ${ }^{\circledR}$ boxes were used with two sheets of Germitest ${ }^{\circledast}$ paper as substrate, which were moistened with distilled water until reaching 2.5 times their dry weight, and then put in B.O.D (Biochemical Oxygen Demand) growth chambers at a constant temperature of $25^{\circ} \mathrm{C}$ with daily 12-h light and 12-h darkness photoperiod for twenty-three days. The seedlings that showed potential to resume their development and originate normal plants were considered normal when developed under favorable conditions (BRASIL, 2009). The germination rate was counted from the first to the twentythird day, at the same time, after sowing, based on the following equation (2).
$G(\%)=\frac{\mathrm{N}_{\mathrm{s}}}{\mathrm{N}_{\mathrm{o}}} \times 100 \%$

where: $\mathrm{N}_{\mathrm{s}}$ is the number of germinated seeds, and $\mathrm{N}_{\mathrm{o}}$ is the number of seeds sown.

The germination potential was determined according to the following equation, which considers the number of seeds germinated on the first day of counting, as suggested by Ling et al. (2014).

$P G(\%)=\left(N_{s} / N_{o}\right) * 100$

The germination speed index refers to the time for seed germination and can be calculated according to the equation suggested by Ling et al. (2014).

$G_{i}=\sum\left(N_{s} \mid\right.$ days $)$

The experiment was arranged in a completely randomized design, and the results were compared by the Tukey test at $5 \%$ probability to analyze the means within each experimental condition. The statistical analyses were performed using the software Origin 8.0.

\section{RESULTS AND DISCUSSION}

\section{Wettability}

The wettability results of the treated and control seeds showed a decay profile of the apparent contact angle when the plasma exposure time increased (Figure 2).

According to the literature, the treatment with nitrogen and oxygen increases the hydrophilic character of the seed surface. Since the present treatment was applied in a low-pressure argon atmosphere, this process is believed to occur based on two simultaneous mechanisms: physical bombardment and bond-breaking without the possible or minimal formation of new functional groups (BILLAH et al., 2021).

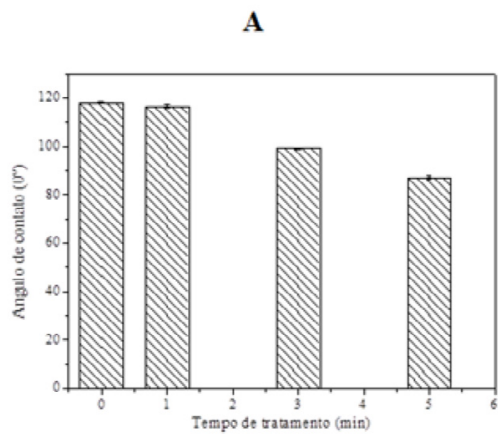

B

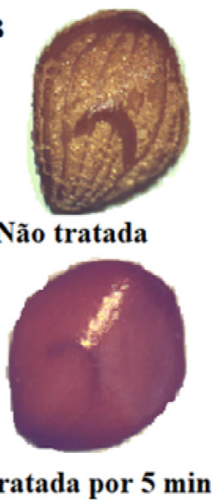

Figure 2. Representation of the apparent contact angle $(A)$ in intact seeds of $D$. virgatus (B) and in seeds treated for $=5 \mathrm{~min}$ (C) 
In physical bombardment (sputtering), the collisions can cause surface cracks and increase the surface roughness, contributing to water removal. The formation of these cavities decreases the contact angle, increasing seed surface wettability due to increased water absorption (ALVES JR et al., 2020; SILVA et al., 2018).

Along with physical bombardment, bond-breaking occurs without the possible or minimal formation of new functional groups. Since the treatment environment is a low-pressure inert gas atmosphere, it has enough kinetic energy to break weaker bonds such as $\mathrm{C}-\mathrm{H}$ and form bonds without significant recombination with plasma elements. This recombination would occur more effectively if more reactive gases were used, such as nitrogen or oxygen (ALVES JR et al., 2020; SILVA et al., 2018).

Figure $2 \mathrm{~B}$ shows the removal of the wax layer, which is hydrophobic and is present in the seed coat of Fabaceae seeds. This layer is composed of a surface deposit of waxy material interfused with a lipoidal substance (b-sitosterol), a subjacent encrustation of the hemicellulose-cellulose complex, and a layer of palisade cells whose secondary walls are impregnated with arabinan, and with tannin and phenolic compounds in the lumen (MANDIZVO and ODINDO, 2019).

It was possible to observe the removal of this layer with plasma exposure (Figure 2B), highlighting the action of the plasma on the physical structures and the chemical interactions, which may modify the process of water capture and entry into the seed.

\section{Water absorption (Imbibition)}

The germination process has several stages, of which imbibition is the first. Water entry occurs due to differences in the water potential between the seeds and the external environment, subsequently increasing the internal volume and rupturing the seed coat. Water then triggers physiological functions

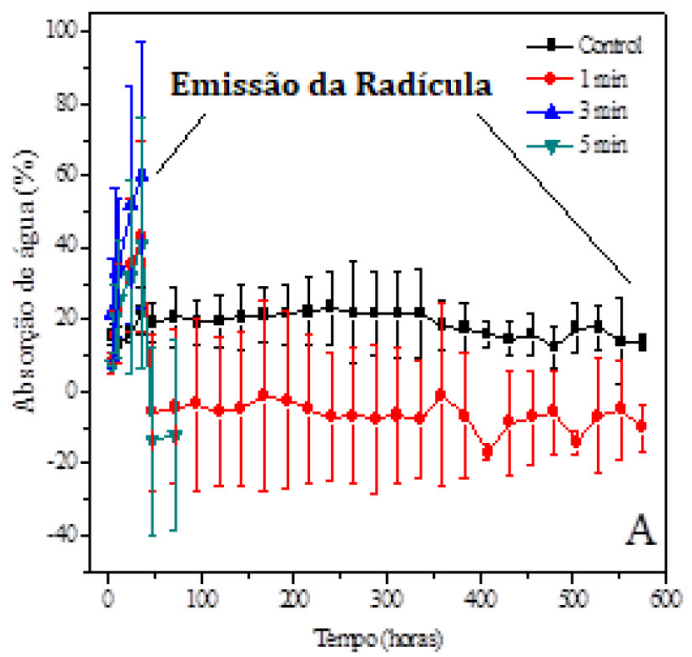

that culminate in radicle emergence and seedling establishment (YODPITAK et al., 2019).

The imbibition curve can be divided into different stages, with physiological modification occurring from the moment when water enters the seed and triggers the germination mechanism (figure 3).

Figure 3 (a) shows the different water absorption times until radicle emergence, when the process ceases. The control seeds had an absorption time of around 576 hours without radicle emergence. A different behavior was verified in the treated samples as each treatment showed a particularity.

In the seeds treated for 1 minute, there was an approximate $8 \%$ mass gain in the first four hours, increasing linearly until 36 hours and decreasing after 48 hours. From this point, water is released at rates that range from $-0.97 \%$ and $-17.00 \%$ until radicle emergence after 576 hours (Figure 3 b). Thus, this treatment resulted in a significant mass gain in the first hours, although having negative points, such as water release and radicle emergence only after 576 hours. However, regarding germination parameters, these samples performed better than the untreated samples.

The seeds treated for 5 minutes showed a linear absorption increase of around $7 \%$ during the first four hours of the test, with a peak value after 36 hours. Subsequently, seed mass decreased by 14 to $12 \%$ from 48 to 72 hours, culminating in radicle emergence.

The results of the imbibition process regarding the first stage of linear water absorption require analysis as to solute release, which occurs naturally. However, when in excess, it may result in loss of viability and correlate with the germination performance of seed lots.

\section{$\mathrm{pH}$ and Conductivity}

The first stage of the germination process involves progressive water absorption by the seed. This stage determines seed

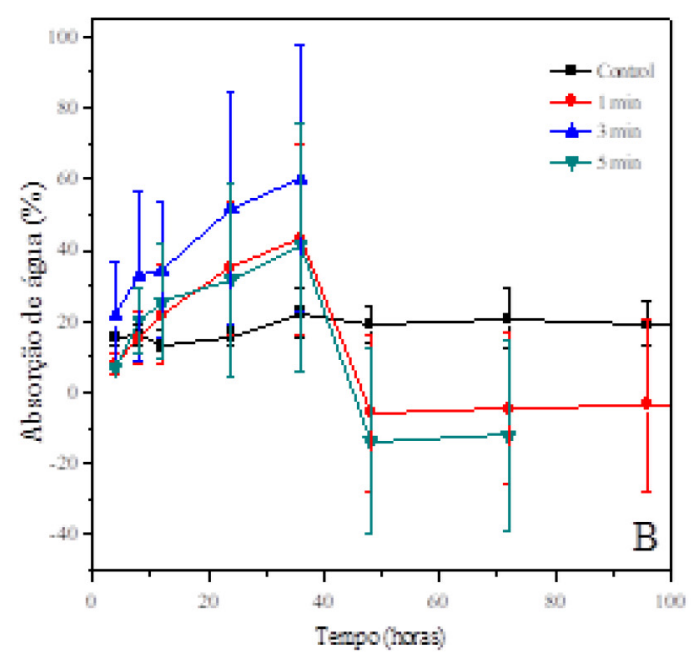

Figure 3. Water absorption in seeds of $D$. virgatus at different plasma exposure times. Full test (A). First 100 hours of the water absorption test (B). 
deterioration by the leakage of solutes, ions, and/or compounds that can modify water parameters, with these analyses being essential to understand the consequent biochemical processes. Studies report that $\mathrm{pH}$ and conductivity are related to seed germination.

One of these relationships refers to the low conductivity value, which implies high physiological quality. On the other hand, low seed vigor is related to large numbers of ions and low $\mathrm{pH}$ (Figure 4).

Figure 4 shows the graphs of $\mathrm{pH}$ and electrical conductivity of the solution obtained during the water absorption test. Figure 4 (a) shows the parameters of the untreated sample, in which the electrical conductivity increases over time, ranging from $7.72 \pm 0.48$ to $55.84 \pm 21.18 \mathrm{mS} . \mathrm{cm}^{1}$. The $\mathrm{pH}$ showed several oscillations over time, ranging from $5.85 \pm 0.03$ to 6.82 \pm 0.30 and alternating between acidic and neutral.

Conductivity also showed a linear increase in the seeds treated for 1 minute, ranging from $2.70 \pm 4.65$ to $51.25 \pm$ 12.46, but with lower values than the untreated sample. The $\mathrm{pH}$ ranged from $6.62 \pm 0.30$ to $7.47 \pm 0.01$, still maintaining neutrality.

The seeds treated for 3 minutes showed radicle emergence after 36 hours. During this time, the conductivity was 9.74 \pm 2.00 and the $\mathrm{pH}$ was $5.87 \pm 0.03$, with low values for both parameters and well below the values of the previous conditions.

In the 5-minute treatment, the samples showed radicle emergence after 72 hours, with conductivity of $11.67 \pm$
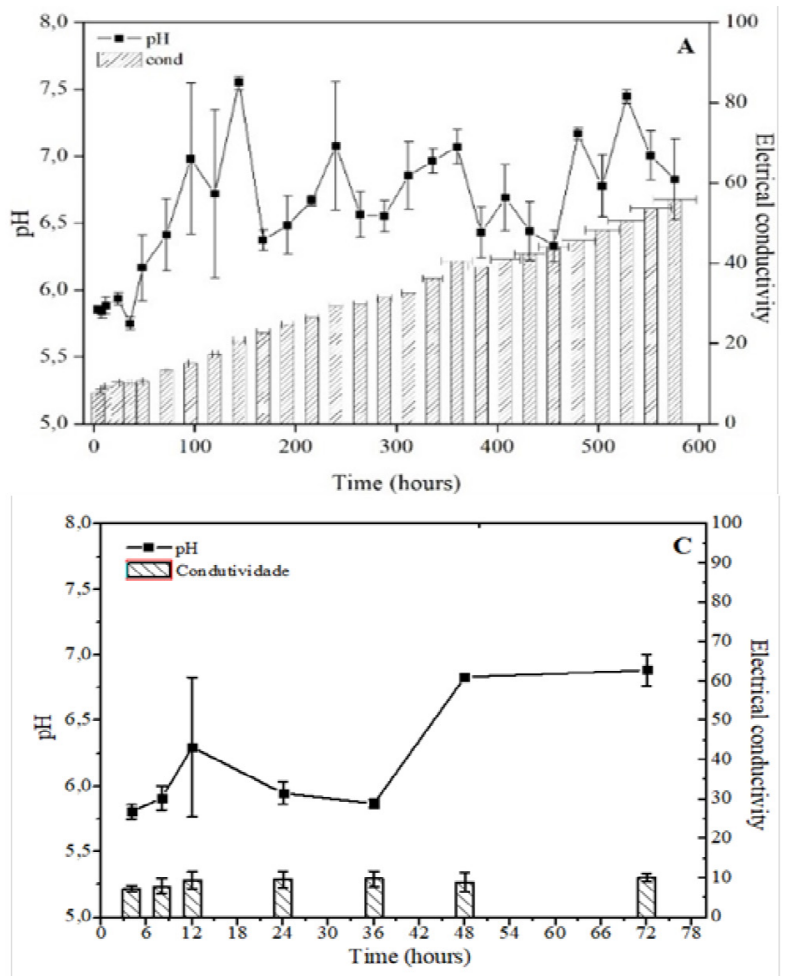

0.47 and $\mathrm{pH}$ of $6.97 \pm 0.01$. When comparing this condition with the 3 -minute treatment, the conductivity showed a similar value within the error, and the $\mathrm{pH}$ increased until reaching neutrality.

Overall, the $\mathrm{pH}$ of the immersion water showed an increasing trend, which can be explained by the release of acidic and basic cations into the water due to the germination process. The materials leached out during imbibition usually consist of inorganic ions, sugars, amino acids, enzymes, nucleosides and nucleotides, and fatty acids.

These results highlight that the control treatment and the 1-minute treatment obtained the highest conductivity values and radicle emergence after a maximum of 576 hours.

This verifies that leaching occurred during germination, by which the seed lost nutrients to the medium, thus increasing the conductivity. For the 3 and 5 -minute conditions, the radicle emerged after 36 and 72 hours, respectively, and the conductivity values were significantly lower, corroborating the idea of SILVA et al. (2018), according to whom low conductivity values promote a more favorable environment for seed germination. The germination mechanism requires seed rehydration, which implies loss of viability, mainly caused by the solute volume leached into the medium.

Solute leaching, measured by electrical conductivity, is directly related to the biological membranes that regulate the influx and efflux of materials and the maintenance of seed viability and vigor. Thus, the conductivity test can
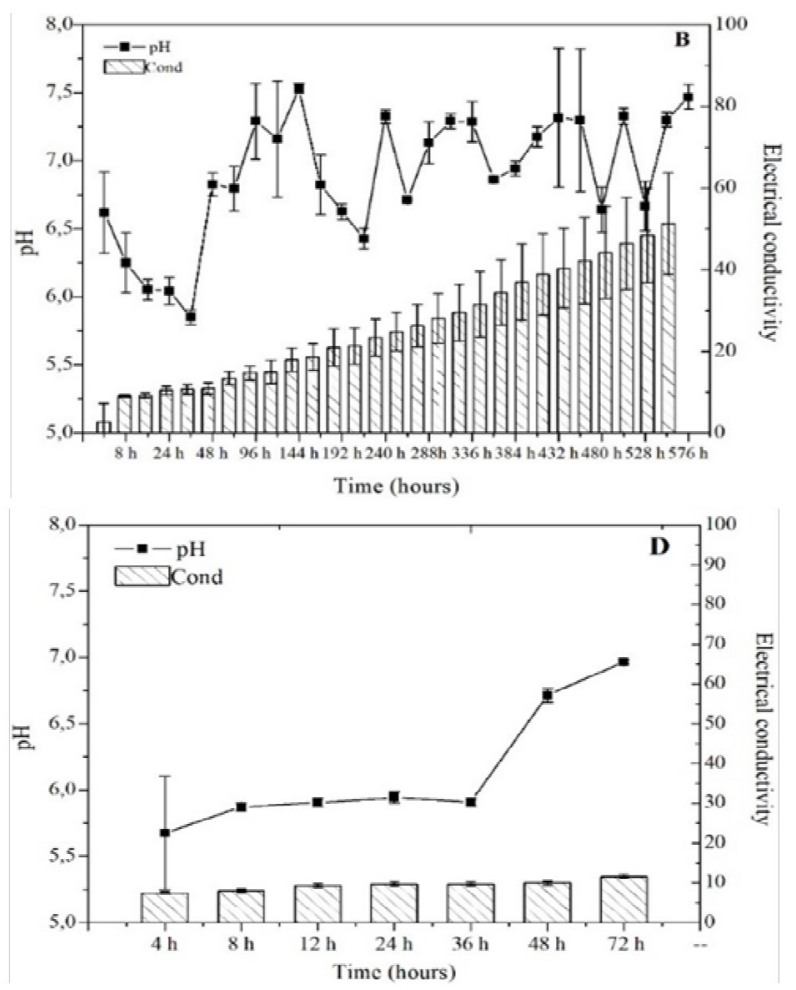

Figure 4. Behavior of $\mathrm{pH}$ and electrical conductivity during the imbibition of seeds of $D$. virgatus under different plasma exposure times. Untreated condition (A); Seeds treated with plasma for 1 minute (B); Seeds treated with plasma for 3 minutes (C); and Seeds treated with plasma for 5 minutes (D). 
be used as an indication of seed vigor since seed lots with high electrical conductivity have lower vigor and probability of germination.

According to Mandizvo and Odindo (2019), after rehydration, solute leakage from the seeds accompanies imbibition, releasing free radicals that result from the accelerated aging of seeds into the cell membranes, resulting in ion leakage (as determined by electrical conductivity).

\section{Germination}

With the results of the tests referring to the germination parameters, it is possible to verify the effectiveness of plasma treatment in improving seed germination compared to the untreated sample (Table 1).

The germination potential increases linearly as a function of treatment duration, based on which it is possible to infer the germination speed of the plasma treatments, resulting in the positive action of low-pressure plasma compared to the control.

Andrade et al. (2020) obtained 79\% germination when studying seeds of Desmanthus, which is higher than the value identified in the present study. However, the authors mention the difficulty in managing the treatment and the size of the studied seeds, complicating the application of conventional dormancy breaking techniques.

Such an obstacle is completely overcome with plasma treatment, considering its indifference regarding seed size as it uses sample containers with appropriate sizes to the different seed diameters within the reactor.
The germination rate provided higher values than the germination potential of the 1 and 3 -minute conditions, the latter of which achieved the maximum value, indicating a higher germination rate.

This value decreased in the 5-minute condition. Finally, the germination speed index data, which indicate continuity and homogeneity during the process, showed that the 5 -minute treatment obtained the highest value, even with lower germination rates. It is supposed that plasma exposure caused excessive membrane disruption, a hypothesis that can be considered when analyzing the electrical conductivity and $\mathrm{pH}$ results.

According to Liu (2019), the reactive species generated by atmospheric ionization and degradation of the membrane surface can directly affect germination due to oxidative stress. According to the same author, these can directly induce lipid oxidation in the seed cell membrane, modifying the normal redox status of seed cells and causing oxidative stress.

When relating the germination parameters to the remaining analyses (contact angle, imbibition, $\mathrm{pH}$, and conductivity), it can be seen that the plasma acts by facilitating water entry into the seed, increasing the germination efficiency and corroborating the results obtained by Sittidet et al. (2019), when subjecting seed species to plasma treatment.

\section{CONCLUSION}

Low-pressure plasma treatment on the seed surface of $D$. virgatus modified the chemical and physiological parameters of the seeds by potentializing the germination parameters, representing a potential technologically and environmentally advantageous alternative to conventional dormancy breaking methods.

Table l. Effects of plasma treatment on the germination parameters of $D$. virgatus.

\begin{tabular}{l|c|c|c} 
Condition & Germination (\%) & Germination potential & $\begin{array}{c}\text { Germination speed } \\
\text { index }\end{array}$ \\
\hline Control & Od & Od & Od \\
\hline Treated for 1 min & $14.67 \mathrm{~b}$ & $8 \mathrm{c}$ & $11 \mathrm{c}$ \\
\hline Treated for 3 min & $18.67 \mathrm{a}$ & $12 \mathrm{~b}$ & $16 \mathrm{~b}$ \\
\hline Treated for 5 min & $12 \mathrm{c}$ & $17 \mathrm{a}$ & $23 \mathrm{a}$ \\
\hline
\end{tabular}

Same letters in the same column $(P>0.05)$ by Tukey's test.

\section{REFERENCES}

ANDRADE, M. V. M.et al. Promoção do desenvolvimento de Desmanthus virgatus $L$. Willd por ação de rizóbios. Revista em Agronegócio e Meio Ambiente, 2020, v.13, n. 2, p. 681-691. doi:10.17765/2176-9168.2020v13n2p68l-691.

ALVES JR. C. et al. Effect of Plasma-Activated Water on Soaking, Germination, and Vigor of Erythrina velutina Seeds. Plasma Medicine, 2019, v.9, n. 2, p. 11l-120. doi.10.1615/PlasmaMed.2019031667.
ALVES JR. C. et al. The water path in plasma-treated Leucaena seeds. Seed Science Research. 2020, v.30, n.1, p. 13-20. doi:10.1017/ S0960258520000045.

BILLAH, M. et al. Investigation of mechanisms involved in seed germination enhancement, enzymatic activity and seedling growth of rice (Oryza Sativa L.) using LPDBD (Ar+Air) plasma. Archives of Biochemistry and Biophysics. 2021. 108726. 
BRASIL. Ministério da Agricultura, Pecuária e Abastecimento. Regras para análise de sementes. Brasília: Mapa/ACS, 2009. 399p.

LING, L. et al. Effects of cold plasma treatment on seed germination and seedling growth of soybean. Scientific Reports. 2014, 4: 5859 I DOI: 10.1038/srep05859.

LIU, M. Bo. Non-thermal atmospheric pressure plasma interacting with water for biological applications. Universite Paris-Saclay. 2019. NNT: 2019SACLX049.

MANDIZVO, T. e ODINDO, A. O. Seed coat structural and imbibitional characteristics of dark and light coloured Bambara groundnut (Vigna subterranea L.) landraces. Heliyon. 2019, v.5, n.2, p. 424-452. doi. org/10.1016/j.heliyon.2019.e01249.

QUEIROZ, I. V. Ocorrência e germinação de sementes de Desmanthus coletadas no semiárido pernambucano. Dissertação (Mestrado em zootecnia) Universidade Federal Rural de Pernambuco. Recife. Pernambuco, p. 80. 2012.
SILVA, D. L. S. et al. Use of atmospheric plasma in germination of Hybanthus calceolaria (L.) Schulze Menz seeds. Revista Caatinga, 2018, v.31, n.3, p.623-629. doi: 10.1590/1983-2l252018v3ln3llrc

SITTIDET, Y., et al. Cold plasma treatment to improve germination and enhance the bioactive phytochemical content of germinated brown rice. Food Chemistry, 2019, v.3, n. 289, p. 328-339. doi. org/10.1016/j.foodchem.2019.03.061.

YODPITAK, S. Cold plasma treatment to improve germination and enhance the bioactive phytochemical content of germinated brown rice. Food chemistry, 2019, v. 289 p. 328-339. doi:10.1016/j. foodchem.2019.03.061

ZHANG, J. J., et al. Plasma Farming: Non-Thermal Dielectric Barrier Discharge Plasma Technology for Improving the Growth of Soybean Sprouts and Chickens. Plasma, 2018, v.l, n.24, p. 285-296. doi. org/10.3390/plasmal020025. 